\title{
Filling the Governor's Position and the Governor's Representative Special Region of Yogyakarta
}

\author{
Prehantoro $^{1} \quad$ Made Warka $^{2} \quad$ Slamet Suhartono ${ }^{3}$ \\ Law Doctoral Program, Faculty of Law, Universitas 17 Agustus 1945 Surabaya
}

\begin{abstract}
Regional autonomy is a follow-up to the implementation of the theory of democracy that was applied through the theory of decentralization. This means that regional autonomy itself is born from decentralization, while decentralization itself is born from the implementation of the essence of democracy. In Indonesia the problem of democracy is regulated in Article 1 paragraph (2) of the 1945 Constitution which states: "Sovereignty is in the hands of the people and carried out according to the Constitution. The change in the paradigm of regional autonomy which was marked by the issuance of Law Number 22 Year 1999 concerning Regional Government, which was later renewed through Law Number 32 of 2004 and renewed through Law Number 23 Year 2014 concerning Regional Government, and there were changes related to points regional head elections which were finally amended by Law Number 2 of 2015, and amended again by Law Number 9 of 2015 concerning Regional Government. It indicates that the dynamics of the legal politics of regional government that are very dynamic and full of challenges in the future to solve them, still keep the polemic warm enough to be a study. The special status for Yogyakarta, Sultan Hamengku Buwono IX and Paku Alam VIII issued a mandate, on September 5, 1945 stating that the Yogyakarta Palace and Pakualaman Temple were special regions of the Republic of Indonesia. The form of relations with the central government is direct and responsible to the President of the Republic of Indonesia. Subsequently on May 18, 1946, Sultan Hamengku Buwono IX and Paku Alam VIII issued Declaration Number 18 which regulated legislative and executive powers.
\end{abstract}

Keywords: special region, governor, decentralization

DOI: $10.7176 / \mathrm{JLPG} / 85-20$

Publication date:May $31^{\text {st }} 2019$

\section{A. Introduction}

The Republic of Indonesia as a unitary state adheres to the principle of decentralization in the administration of government, by providing opportunities and flexibility to the regions. Therefore, the provisions of Article 18 of the 1945 Constitution of the Republic of Indonesia (here in after abbreviated as the 1945 Constitution), among others determine:

(1) The Unitary State of the Republic of Indonesia is divided into provincial regions and the provincial area is divided into regencies and cities, which are types of provinces, districts and cities that have regional regional governments, which are regulated by law.

(2) Provincial, regency and city governments govern and administer government affairs according to the principle of autonomy and co-administration.

(3) Provincial, district, and municipal governments have a Regional People's Representative Council whose members are elected through general elections.

(4) Governors, Regents and Mayors respectively as heads of government and provinces, districts and cities are democratically elected.

(5) Regional governments carry out autonomy to the greatest extent possible, except for government affairs which are determined by law as central government affairs.

(6) The regional government has the right to establish regional regulations and other regulations to implement autonomy and assistance tasks.

(7) The structure and procedures for administering regional government are regulated by law.

Philipus M. Hadjon argues that there are 4 principles underlying the provisions of Article 18 of the 1945

Constitution, namely:

1. The principle of regional division which is hierarchical in paragraph (1);

2. The principle of autonomy and co-administration in paragraph (2);

3. The principle of democracy in paragraph (3) and paragraph (4); and

4. The principle of autonomy is as broad as possible in paragraph $(5) .^{4}$

The People's Consultative Assembly (MPR) in its official publication on the Guidelines for promoting the

\footnotetext{
${ }^{1}$ Student of Law Doctoral Program, Faculty of Law, Universitas 17 Agustus 1945 Surabaya, prehantorosby@gmail.com.

${ }^{2}$ Lecturer of Law Doctoral Program, Faculty of Law, Universitas 17 Agustus 1945 Surabaya, made@untag-sby.ac.id.

${ }^{3}$ Lecturer of Law Doctoral Program, Faculty of Law, Universitas 17 Agustus 1945 Surabaya, slamet@untag-sby.ac.id.

${ }^{4}$ Philipus M. Hadjon, Perlindungan Hukum bagi Rakyat di Indonesia, Sebuah Studi tentang Prinsip-prinsipnya, Penanganannya oleh

Pengadilan dalam Lingkungan Peradilan Umum dan Pembentukan Peradilan Administrasi Negara, Bina Ilmu, Surabaya. 1987, p. 45.
} 
1945 Constitution states that there are 7 principles that become the paradigm and political direction underlying Article 18, and Article 18B of the 1945 Constitution, namely:

1. The regional principle regulates and manages government affairs according to the principle of autonomy and task of assistance (Article 18 paragraph (2)

2. The principle of carrying out the widest possible autonomy (Article 18 paragraph (5)

3. Principles of regional specificity and diversity (Article 18 paragraph (1)

4. The principle of recognizing and respecting customary law community units and their traditional rights (Article 18B paragraph (2)

5. The principle of recognizing and respecting the Special and Special Regional Government (Article 18B paragraph (1)

6. The principle of a representative body is directly elected in a general election (Article 18 paragraph (2)

7. The principle of relations between the center and the regions is carried out in a harmonious and fair manner (Article 18B paragraph (2).

Regional autonomy is a follow-up to the implementation of the theory of democracy that was applied through the theory of decentralization. This means that regional autonomy itself is born from decentralization, while decentralization itself is born from the implementation of the essence of democracy. In Indonesia the problem of democracy is regulated in Article 1 paragraph (2) of the 1945 Constitution which states: "Sovereignty is in the hands of the people and carried out according to the Constitution.

The change in the paradigm of regional autonomy which was marked by the issuance of Law Number 22 Year 1999 concerning Regional Government, which was later renewed through Law Number 32 of 2004 and renewed through Law Number 23 Year 2014 concerning Regional Government, and there were changes related to points regional head elections which were finally amended by Law Number 2 of 2015, and amended again by Law Number 9 of 2015 concerning Regional Government. It indicates that the dynamics of the legal politics of regional government that are very dynamic and full of challenges in the future to solve them, still keep the polemic warm enough to be a study. As stated in the explanation of Law Number 13 of 2012 concerning the Privileges of the Special Region of Yogyakarta, it is stated that the special status inherent in DIY is an integral part of the history of the establishment of the Indonesian nation.

The choice and decision of Sultan Hamengku Buwono IX and Duke of Paku Alam VIII to be part of the Republic of Indonesia, as well as its contribution to protect the symbol of the nation in the early days of independence have been recorded in Indonesian history. This is a philosophical reflection of the Sultanate, Duchy, and the people of Yogyakarta as a whole which glorifies diversity in unity as stated in Pancasila and the 1945 Constitution.

The homogeneous Yogyakarta community at the beginning of independence merged into a pluralistic society, both ethnic, religious and traditional. That choice brought the people of Yogyakarta into a small part of Indonesian society. Therefore, the Specialization of DIY must be able to build harmony and social cohesiveness in justice.

Privileges arrangements include the procedures for filling in positions, positions, duties, and authority of the Governor and Deputy Governor, Institutions of DIY Regional Government, Culture, Land, and Spatial Planning. Thus, the DIY Regional Government has authority that includes special authority based on Law Number 13 of 2012 and authority based on the law on Regional Government. However, the authority that has been owned by the Regency / City Government of DIY remains in accordance with the laws and regulations.

One of the symbols of DIY's specialty is related to filling in the positions of Governor and Deputy Governor, which are the rights of the internal Sultanate and Duchy itself where the King of the Sultanate becomes the Governor and King of Puro Pakualaman to become Deputy Governor. Charging the position of Governor and Deputy Governor is the most crucial issue at the time of the promulgation of the law on Yogyakarta privilege. The emergence of pros and cons regarding filling in the positions of the Governor and Deputy Governor with various accompanying arguments would inevitably have an impact on the process of drafting the law on privileges. Through this Act No. 13 of 2012, Sultan Hamengku Buwono and KGPAA Paku Alam who were enthroned automatically were appointed as Governors and Deputy Governors of the Special Region of Yogyakarta.

\section{B. Problem Formulation}

Based on the description in the background of the problem, problems can be formulated in this study:

a. What is the ratio legislation for filling in the position of Governor and Deputy Governor of the Special Region of Yogyakarta?

b. How do you fill the position of Governor and Deputy Governor of the Special Region of Yogyakarta in a democratic perspective?

\section{Research Method}

The legal material collection technique in this dissertation study begins with a literature study, namely an inventory of all legal materials related to the subject matter, both primary legal material, and secondary legal material. Then 
the classification of related legal materials is held, then the legal materials are arranged systematically to more easily read and study them. Legal material obtained from library studies, then collected and grouped, to be selected and sorted according to the character of the legal material needed; especially those that have relevance to the issues discussed. For legal material that is less relevant, it is temporarily set aside, and will be used if the legal material is needed

\section{Discussion Results}

1. Ratio Legis Fill in the Position of Governor and Deputy Governor of the Special Region of Yogyakarta As Part of the Privileges of Yogyakarta

The State recognizes and respects regional government units that are special or special in nature which are regulated by law. The State recognizes and respects customary law community units and their traditional rights insofar as they are still alive and in accordance with the development of society and the principles of the Unitary State of the Republic of Indonesia, which are regulated in law.

Specificity or privilege given by the government to the regions is possible according to the mandate of Article 18B paragraph (1) of the 1945 Constitution which states: "The State recognizes and respects regional government units that are special or special in nature regulated by law". The provision of special autonomy and privileges in my opinion will not endanger the NKRI. Our country is still a unitary state. Only to those regions because of their status as special regions or special regions, the government surrenders wider and more extensive authority. In carrying out its authority, these regions cannot be separated from the constitution and the system of government established by the central government. This practice is in line with the concept of asymmetrical decentralization and empirically found in other countries in the world, such as the Quebec region in Canada, Basque in Spain, Moro in the Philippines, and Bougenville in Papua New Guinea.

Regional Government is the administration of government affairs by the Regional Government and DPRD according to the principle of autonomy and co-administration with the broadest principle of autonomy in the system and principles of the Unitary State of the Republic of Indonesia as referred to in the 1945 Constitution. Provincial Regional Government consists of Provincial Regional Government and Provincial DPRD. Regency / City Regional Government consists of Regency / City Regional Government and Regency / City DPRD.

If the provisions of Law Number 32 Year 2004 continue to be used in the administration of government in the Province of Yogyakarta, the provision violates the provisions contained in Article 18 of the 1945 Constitution of the Republic of Indonesia. Provisions in Law Number 32 Year 2004 do not comply with the socio-political state of the people of the Special Province of Yogyakarta who wanted the Sultan to remain as governor or head of government in the Special Province of Yogyakarta. ${ }^{1}$

Yogyakarta (or Yogyakarta) and often abbreviated as DIY is a province in Indonesia which is located in the southern part of Java Island and borders the Central Java Province in the north. Geographically, Yogyakarta is located on the central part of Java. The area was hit by an earthquake on May 27, 2006 which resulted in 1.2 million people not having a home.

DIY Province has a public service supervision institution called the Yogyakarta Regional Ombudsman which was formed by the DIY Governor's Decree. Sri Sultan HB X in 2004. The Special Region of Yogyakarta is a province based on the Ngayogyakarta Hadiningrat Sultanate region and the Pakualaman Duchy. In addition, it was also added to the former Surakarta Hadiningrat Sunanate area and Mangkunagaran Praja which were previously enclaves in Yogyakarta.

a. Early History of the Establishment of the Special Region of Yogyakarta

The Special Region of Yogyakarta could be traced back to 1945, even before that. A few weeks after the Proclamation of August 17, 1945, at the insistence of the people and after seeing the conditions, Hamengkubuwono IX issued a royal decree known as the Mandate of September 5, 1945. The contents of the decree were the integration of the Yogyakarta monarchy into the Republic of Indonesia.

Decrees with similar contents were also issued by Paku Alam VIII on the same day. Such a decree of integration with the Republic of Indonesia was actually also issued by various monarchies in the archipelago, although not a few monarchies awaited the establishment of the Indische Netherlands government after Japan's defeat.

At that time the power of the Yogyakarta Sultanate included:

1) Regency of Yogyakarta City with its head of KRT Hardjodiningrat;

2) Sleman Regency with its head of KRT Pringgodiningrat;

3) Bantul Regency with its regent KRT Joyodiningrat;

4) Gunungkidul Regency with its regent KRT Suryodiningrat;

5) Kulonprogo Regency with its regent KRT Secodiningrat. ${ }^{2}$

\footnotetext{
${ }^{1}$ http://www.setneg.go.id/index.php?Option=com_content\&task =view\&id $=3519 \&$ Itemid $=281$.

${ }^{2}$ https://eprints.uns.ac.id/363/1/151151908201009321.pdf.
} 
Whereas the power of Praja Paku Alaman includes: 1) City District of the Spikes with the heads of the KRT Brotodiningrat; and 2) Adikarto Regency and its regent KRT Suryaningprang. By utilizing the momentum of the formation of the Yogyakarta Regional Committee of the Indonesian National Committee on October 29, 1945 with chairman Moch Saleh and deputy chairman S. Joyodiningrat and Ki Bagus Hadikusumo, then the following day, it was as conspicuous as the Regional Work Committee of the Yogyakarta KNI, Hamengkubuwono IX and Paku Alam VIII issued a decree the kingdom together (known as the Mandate of October 30, 1945) which contained the delegation of legislative power to the Yogyakarta Regional KNI Work Agency. From then on, the two royal rulers in southern Java issued a joint decree and began the union of the two kingdoms.

Since then the royal decree was not only signed by the two monarch rulers but also by the chairman of the Yogyakarta Regional KNI Workers' Body as a symbol of people's agreement. The development of the united monarchy experienced ups and downs.

On May 18, 1946, officially the name of the Special Region of Yogyakarta began to be used in government affairs emphasizing the union of two royal regions to become a special region of the State of Indonesia. The use of this name is contained in Notification 18 of the House of Representatives in the Special Region of Yogyakarta. The monarchical unity government continued until the issuance of Law No. 3 of 1950 concerning the establishment of the Special Region of Yogyakarta which confirmed the area of the Sultanate of Yogyakarta and the Paku Alaman area was an integral part of the State of Indonesia. The provisions of Article 1 of Law Number 3 of 1950 explain: "(1) Regions covering the territory of the Sultanate of Jogjakarta and the Paku Alaman area are designated as Special Regions of Jogjakarta. (2) The Special Region of Jogjakarta is on a level with the Province."

The Province of Yogyakarta Special Region consists of 4 districts and 1 city. The capital is Yogyakarta. The following is a list of districts and cities in the Special Region of Yogyakarta, along with the district capital, namely: 1) Bantul Regency with the capital of Bantul; 2) Guning Kidul Regency with the capital of Wonosari; 3) Kulon Progo Regency with the capital of Wates; 4) Sleman Regency with the capital Sleman. Coupled with the city of Yogyakarta.

b. Government

The foundation of the regional development philosophy of the Special Region of Yogyakarta is Hamemayu Hayuning Bawana, as a noble ideal to perfect the values of the life of the people of Yogyakarta based on regional cultural values that need to be preserved and developed. Other philosophical foundations are HamangkuHamengku-Hamengkoni, Throne for the People, and Throne for Socio-cultural Welfare.

The Government of the Special Region of Yogyakarta was formally legally formed by Law Number 3 Year 1950 (State Gazette Year 1950 Number 3) and Law Number 19 Year 1950 (State Gazette Year 1950 Number 48) which came into force from 15 August 1950 with Government Regulation Number 31 Year 1950 (State Gazette of 1950 Number 58). Law No. 3 of 1950 concerning the Establishment of the Special Region of Yogyakarta has a very short content with 7 articles and an attachment to the list of autonomous authorities. The law only regulates the territory and capital city, the number of DPRD members, the kinds of authority of the Special Regional Government, and the rules which are transitional in nature. Law Number 19 Year 1950 itself is a revision of Law Number 3 Year 1950 which contains additional authority for the Special Region of Yogyakarta.

The division of the Special Region of Yogyakarta into districts and cities that are autonomous and regulated by Law Number 15 Year 1950 (State Gazette Year 1950 Number 44) and Law Number 16 Year 1950 (State Gazette Year 1950 Number 45). The two laws were enacted by Government Regulation No. 32 of 1950 (State Gazette of 1950 Number 59) which regulated the Special Region of Yogyakarta to become regencies:

1) Bantul has its capital in Bantul;

2) Sleman has a capital city in Sleman;

3) Gunung Kidul has its capital in Wonosari;

4) Kulon Progo has its capital at Sentolo;

5) Adikarto is the capital of Wates;

6) Big City of Yogyakarta.

For reasons of efficiency, in 1951, the Adikarto district with its capital in Wates was merged with Kulon Progo district, which had its capital in Sentolo to become Kulon Progo Regency and the capital city of Wates. The merger of these two regions was based on Law Number 18 of 1951 (State Gazette of 1951 Number 101). All Laws concerning the establishment of the Special Region of Yogyakarta and the District and City in its environment, are formed based on the Basic Law on Regional Government (Law Number 22 Year 1948). Furthermore, for the smooth running of governance, in accordance with the motion of the House of Representatives of the Special Region of Yogyakarta Number 6/1952 dated September 24, 1952, the Imogiri enclave areas , Kota Gede, and Ngawen were released from the Central Java Province and the relevant districts were then put into in the territory of the Special Region of Yogyakarta and the districts whose territory encircles the enclave areas .

This enclave-enclave union is based on Emergency Law Number 5 of 1957 (State Gazette of 1957 Number 5) which was later approved by the DPR into Law Number 14 of 1958 (State Gazette of 1958 Number 33 , Supplement to State Gazette Number 1562). 
c. The concept of choosing a Regional Head based on the Privilege Bill

This concept will highlight the constitutional rights of the people of Yogyakarta which are an integral part of the NKRI. The problems that have arisen so far, are for the people of Yogyakarta based on the history and constitutional mechanism of the establishment of the NKRI where the Governor and Deputy Governor positions are attached to the Sultan and Pakualam, so there is no Election of Regional Heads, but only by Determination, on the other hand The Regional Head, on the grounds that at this time should have been established normative Democracy and legal based on Law Number 32 Year 2004, namely Article 56 of Law Number 32 Year 2004 states that the Regional Head must be democratically elected, so that the brief must be through the Election mechanism. not determination.

If it is pursued since the beginning of the establishment of the Government Act in the region, namely the Presidential Decree Number 6 Year 1959, then Law Number 22 Year 1948 until Law Number 5 Year 1974 there is already an affirmation of the Speciality of the Yogyakarta Region, which in principle states that Special Regional Heads are appointed by the president of the family descendants who are "in power" as a tribute to the sacrifice and support given to the NKRI. Therefore the Head of the Special Region of Yogyakarta is a descendant of Sultan Hamengku Buwono and his Deputy Head of Region are from the descendants of Sri Paduka Paku Alam. Then the statement arose why when the Regional Government Law was discussed, Law No. 32 of 2004, our people's representatives, especially people's representatives from the Special Region of Yogyakarta, did not include the rights of this Special Region which is an integral part of the translation of Article 18B of the Constitution 1945.

Therefore, in fact, before the birth of the Bill of Jurisdiction, the people of Yogyakarta could legally file a Judicial Review lawsuit with the Constitutional Court, because the Constitutional Rights of the People of Yogya had been harmed by the birth of Law No. 32 of 2004. The testing of Law No. 32 of 2004 was based on the loss of the Yogya People's Constitution, because we know that constitutional losses can be appointed in a lawsuit to the Constitutional Court against the testing of Law Number 32 of 2004 due to the contents and material content of Law Number 32 The year 2004 does not contain the Special Rights of the Region, even though in Article 18B the 1945 Constitution regulates the recognition and respect for special regional administrations such as the Special Region of Yogyakarta.

However the Yogya People's Constitutional Rights must be respected as one of the reasons for formulating the lawsuit material to the Constitutional Court. The process of material judicial rights can also apply when RUUK if it will become the Speciality Act of Yogyakarta and it is not in accordance with the aspirations and historical values of the birth of the Special Region of Yogyakarta. But it would be appropriate if the first question was the matter of Law Number 32 Year 2004, if it turns out that the Constitutional Court granted and would be amended Law Number 32 of 2004, the DPR-RI which was preparing the RUUK would pave the way to accommodate Rights Yogyakarta Special Region which will eventually lead to the Determination of Regional Heads, not Elections.

Now it depends on the willingness of the people of Yogyakarta to legally oppose the legality of the existence of Law No. 32 of 2004 and it is known in Yogyakarta that the warehouses of experts, especially legal experts to gather discuss legal steps that must be carried out in the future, instead of doing pressure that might result anarchists, even though it is known to Yogya people who are famous for their manners.

The position of the Sultan is very clearly stated in this Draft Bill of Privileges in Article 1 and Article 9, namely as Governor. The position of the Sultan is explained as a consequence of the privilege of Yogyakarta. The Sultan as Governor is appointed based on his descent so that the vacancy as a result of the Sultan is unable to remain filled by others (Article 16). Mentioned in Article 10, the DPRD proposes the Sultan to be appointed as Governor to the President. If within 3 months the DPRD does not propose the Sultan to be the Governor, the President has the right to automatically appoint the Sultan as Governor. Article 11 further explains that if the Sultan has not fulfilled the requirements as governor as determined by the applicable law, then the Deputy Governor who is none other than the Duke of Paku Alam will carry out his duties as acting Governor. as head of an autonomous region and as a representative of the central government (deconcentration).

From these two different points of view, it appears that the main problem in the position of the Sultan is how to place the Sultan in his honorable position in the Yogyakarta community. This problem is an issue that is viewed from below, from the point of view of the community. The problem with the position of the Sultan is a big problem when democratization becomes a new phenomenon in Indonesian society in general, and Yogyakarta in particular. Therefore, this study will try to answer the above problems by outlining the position of the Sultan in the context of the Kingdom of Mataram and the problem of that position in the context of democratization.

Sultan Hamengku Buwana IX has proven himself as the King who is able to become a liaison between the center and the region. Every change in political dynamics at the central level is always followed and then followed up with policy changes at the local level. Thus, the position of the Sultan is a guarantee from the central government that Yogyakarta will not release itself from the NKRI. The struggle of Sultan Hamengku Buwana IX, which was then continued by Hamengku Buwana $\mathrm{X}$ at this time to demand privileges to be maintained, was not a struggle to demand the Yogyakarta government as a democratic political institution because the direction to be pursued was the continuation of the Yogyakarta Sultanate. This statement is supported by the fact that the location of privileges 
is always placed in the corridor of the Sultan as Governor automatically, without having to be elected by the people or representatives of the people and without having to be held accountable for the administration of the people or people's representatives (DPRD).

So, the privilege that was fought for was the struggle towards the preservation of the feudal system which was willing to base itself on the primordial loyalty of its people. Therefore, the realization of the Privileges of Yogyakarta will in turn foster a new centralism of power at the local level. But this danger can be eliminated because the Sultan is placed as a bureaucrat from the central government so that even though the Sultan becomes the Governor, he does not have any political power over his territory other than the 3 affairs mentioned above. Privileges also contain substances that need attention. In addition to aspects of the origin of history and its role in the struggle for the birth of the Republic of Indonesia, governance procedures included succession of regional heads, aspects of land (land of magersari ) and cultural aspects.

\section{Charging the Position of Governor and Deputy Governor of the Special Region of Yogyakarta in the Democratic Perspective}

In Indonesia, the discourse of democratization shows a person who is increasingly able to feel and touch everyday life. Whoever, at present, is meaningfully demonstrating activities and practices in the name of democracy, while everything gets a lawsuit in the name of democracy. The problem is, because in the name of democracy social mechanisms related to public policy matters are often seen running riotous, and violence arises everywhere. If examined, inevitably in the name of democracy and human rights (HAM) many people become brave enough to do anything.

This, it is possible that activity in the name of potential democracy contains authoritarianism and anarchy. Then, there is always a defense, that it is not democracy, but a game and maneuver of a few interested parties. That is, behind many incidents of violence, the political game of power in the name of democracy was made a scapegoat.

Apart from that, what we want to say is that democracy does not guarantee life to be peaceful and peaceful, full of respect for human rights, people get justice and guarantees transparent law, politics is run honestly and fairly, and all understandings of democracy for everyone who hopes democratic life.

In the end, it is increasingly proven that democracy is not something that can operate universally. He always experiences contextualization, depending on where and when the concept of democracy is enforced and defined. Therefore, never expect democracy in the universal and ideal sense to be applied in all public spaces. America, for example, which considers its most democratic country, feels that implementing democracy is "pure", in practice it always has a double standard in managing the definition of democracy in accordance with the interests of the state and the American people. But that is American democracy. America always claims that many countries do not run democratically and need to learn American democracy.

Indeed, the guarantee of the American people to obtain democratic legal rights in their daily lives may be the most tolerable compared to a number of other countries. But that does not guarantee that the American state is free from violations of democracy in its various aspects. What is certain is that American democracy is not able to guarantee that people can live peacefully, peacefully and prosperously. That is why, it is said that the practice of democracy does not have to be applied in a modern way, but the "traditional" ways of society have their own way of calling themselves domocratic.

In this case, what is interesting is the Yogyakarta-style democracy, which is called the dualism of democracy. The basis of this dualism concept borrows the concept of economic dualism, ie when modern (traditional economic mechanisms and systems) go hand in hand, complementary and synergistic.

In Yogyakarta, modern and traditional democracies go hand in hand, and that is also a mechanism that is able to secure Yogyakarta from various violence and mass riots. If there is rioting and mass violence that loses and is threatened by life are people, nobody.

What is meant by the dualism of Yogyakarta-style democracy, namely in terms of allowing modern democracy to run in Yogyakarta, for example the demands of a system of government and inclusive decision making, the administration of accountable and transparent governance, the existence of representative and responsive representative institutions, civil liberties and the media, people's participation in the administration of government, the life of a pluralist and peaceful society, and others.

On the other hand, do not force the Yogyakarta people not to respect the Sultan, who in the eyes of modern democracy is considered feudal and undemocratic. It cannot be said, that people who "worship" the Sultan are then called undemocratic. Yogyakarta traditional democracy has its own way. If they believe in what the Sultan says, why should they be blamed. That is the contextualization of democracy.

The modern history of Yogya has proved that modern democracy is running riot, and in the end what can secure Yogyakarta is the interference of Yogyakarta-style democracy. Namely the Sultan's authority as the Father and Parents of Yogya, as well as the support of the Yogyakarta people who respect the Sultan. It is not necessary for people who serve the Sultan to be considered ancient and undemocratic. People have their own way of life according to what they believe. We don't know whether that way they might actually be happier.

The influence and prestige of the shadow of the Sultanate of Yogyakarta will be stronger, or there are a 
number of other processes so that the tradition will diminish so that the process of Yogyakarta-style feudalism leads to new forms. In fact, the Sultanate of Yogyakarta was able to provide a kind of security, enjoyment, and asylum to feel more civilized to (become) the people of Yogyakarta, then the dualism of democracy would be stronger. What can be felt now, within certain limits, Yogyakarta provides the convenience of modern democracy in the control of the shadow of the Sultan's power that is able to protect the people of Yogyakarta.

Shortly after being appointed by the President of the Republic of Indonesia, Susilo Bambang Yudhoyono, as Governor of the Special Region of Yogyakarta, Sri Sultan Hamengku Buwono X stated, "what is expected so far has finally been realized". The inauguration of Sri Sultan Hamengku Buwono X as Governor and KGPAA Pakualam IX as Deputy Governor of DIY on October 10, 2012 was the final marker of the long dynamics of the struggle process in obtaining DIY legality and privilege status. The polemic about privileges by filling in the positions of Governor and Deputy Governor as the central issues that have occurred since 1998 has become an anticlimax. Even the inauguration of the Governor and Deputy Governor in Gedung Agung without cheering like a celebrity event.

People who previously actively participated in various efforts to struggle for privileges and even reactive to take to the streets were still cool. Sacred inauguration events are like being separated from public attention. The issue of privilege re-emerged in the middle of the public when there was a discussion of the Parent Regional Regulation by the local government together with the DIY DPRD in August 2013 and the Special Regional Regulation on the Provision of DIY Governor and Deputy Governor's Office in 2015. the public is related to the formulation of the requirements for the Governor and Deputy Governor Candidates who wish to be included in the article Special Region Regulation (Perdais) as a derivative of the Privileges Law.

This polemic is quite warm in the public when the attitude in the DIY DPRD is fragmented on the two poles between the poles, which agrees and the counter is explicitly included in curriculum vitae as one of the requirements of the Governor and Deputy Governor of DIY in the Chancellor for the Governor and Deputy Governor of DIY. This polemic then subsided after the DIY DPRD agreed unanimously to the entry of "wife's curriculum vitae" as a requirement for the Governor and Deputy Governor of DIY.

Among the sensitive points in the requirements are the "wife" curriculum vitae which must be fulfilled by the governor and deputy governor candidates. The existence of the word "wife" in the provisions that mention the wife's curriculum vitae contains an understanding, that the king who is enthroned must be a man. While Sultan Hamengku Buwono $\mathrm{X}$ who is now enthroned is known to only have a daughter. The polemic that developed in the public then spread to the issue of succession in the Sultanate.

Even more so when inside the Sultanate there is also a political dynamic that is heating up following the King's Word and three Tama Words issued by Sultan Hamengkubuwono X in just three months, March to May 2015.

In the Kraton perspective, the word of the King was issued for the internal interests of the Sultanate while Sabda Tama was interpreted both for internal and public interests in general. Seeing the sequence of the release of the king's words and the sequential words of his time is relatively close, it is certainly difficult to avoid the scent and impression of the existence of motives and political intrigue within the Sultanate. It was different from the nuances and inner atmosphere when Sultan Hamengku Buwono $\mathrm{X}$ issued his first statement to respond to the Privileges Act in 2012.

At that time, the first Word was issued with the intention of responding to the developing situation and conditions related to the stipulation of the Privilege Bill into law. The Sultan as the King who represented the Sultanate deemed it necessary to affirm the Sultanate's political position in relation to the dynamics of discussing the Privilege Bill in the Indonesian Parliament which would soon be promulgated. At that time the entire family of the Sultanate of the Sultanate looked solid and a command was immediately enacted.

In the first statement delivered on March 6, 2015, Sultan Hamengku Buwono X responded more to the development of polemics in the public as the excesses of the debate over the discussion of the points in the Draft Regional Regulation (Raperdais) currently taking place in the DPRD DI Yogyakarta. The polemic that has occurred has gone far. Not only does the question need to or not include the "wife" curriculum vitae as an administrative requirement that must be met by the governor and deputy governor candidates in special (perdais) regional regulations as also stipulated in Law No. 13 of 2012. But it has already penetrated in the discourse of succession in the Sultanate Palace.

Through the first word, explicitly Sultan HB X needs to emphasize that the matter of succession in the Yogyakarta Palace has been determined and there is a mechanism therefore the public outside the Sultanate walls are asked not to interfere. On the words of the king issued 30 April 2015, Sultan HB X changed his name from Buwono to Bawono and eliminated the title of Kalifatullah and changed the title of kaping as if it was ten chapels. In addition, Sultan HB X also declared renewing the agreement of the founders of Mataram, namely Ki Ageng Giring and Ki Ageng Hatiahan and perfecting the kereng ageng (agung) Keraton Yogyakarta, Kiai Kopek and Kiai Joko Piturun as symbols of the kingdom of Mataram Sultanate. The king's words then continued with the words of the king delivered on May 5, 2015, which changed the name of GKR Pembayun, the eldest daughter of Sultan 
HB X became GKR Mangkubumi Hamemayu Hayuning Bawono Langgeng ing Mataram. A royal ritual that can also be interpreted as the appointment of the crown princess even without being accompanied by the surrender of the kiai Joko Piturun as a symbol of the crown prince's kris. By giving that name, Sultan HB X placed GKR Pembayun (Mangkubumi) as a crown princess and a future leader who was expected to be able to provide safety, happiness and prosperity to anyone. Sultan HB X put his eldest daughter as his successor. The sign of preparation for power at the Yogyakarta Palace was reinforced by the selection of the name Mangkubumi for GKR Pembayun, such as the name Sultan HB X before becoming the sultan or the name of the founder of the Yogyakarta Palace, namely Prince Mangkubumi.

\section{E. Conclusion}

Based on the description described in the previous chapters, it can be concluded as follows:

Ratio legislation for filling in the position of Governor and Deputy Governor of the Special Region of Yogyakarta (DIY) is one of the authorities specified in Act No. 13 of 2012 concerning the Privileges of the Special Region of Yogyakarta. The filling in of the Governor and Deputy Governor of DIY Position is carried out through a determination mechanism, which is procedurally carried out by the DIY Regional Representative Council (DPRD). The mechanism of determination is carried out every five years for Sultan Hamengku Buwono and Duke of Paku Alam who are reigned as Governors and Deputy Governors from the year of inauguration, and are not bound by the periodic terms of office as stipulated in Law Number 13 of 2012, then become Special Regional Government Laws. .The determination of the Governor and Deputy Governor is carried out without leaving the principle of democracy in the life of the nation and state. Charging Position. If the Sultan and / or Paku Alam who are enthroned do not fulfill the requirements, as stipulated in Article 18 of Act No. 13 of 2012, if only Sultan Hamengku Buwono is enthroned as deemed fulfilling the requirements, the DIY DPRD shall determine Sultan Hamengku Buwono who reigns as Governor. As Governor, Sultan Hamengku Buwono, who reigned and carried out the duties of Deputy Governor until Adipati Paku Alam, who was inaugurated was appointed as Deputy Governor. Vice versa. If Sultan Hamengku Buwono and Sri Paku Alam who enthroned simultaneously did not fulfill the requirements as Governor and Deputy Governor of DIY,then the Government appoints Governor Officials after obtaining the consideration of the Sultanate and the Duchy, until the inauguration of Sultan Hamengku Buwono who reigns as Governor and / or Duke of Paku Alam who reigns as Deputy Governor. The filling of the positions of the Governor and Deputy Governor of the Special Region of Yogyakarta that use the stipulation is in accordance with the principle of democracy. The essence of democracy itself is the highest power in the hands of the people. Article 1 paragraph (2) of the 1945 Constitution states that sovereignty is in the hands of the people and carried out according to the Constitution. Although in the filling of the Governor and Deputy Governor of the Special Region of Yogyakarta there was no open political recruitment, the desire of some people of the Special Region of Yogyakarta so that the Sultan became Governor was very large.

Suggestions that can be taken are that the Regional Government is expected to immediately form a Special Special Regional Regulation regulating the Filling of the Position of Governor and Deputy Governor of the Yogyakarta Istimewa Region as one of the mandates in Law Number 13 of 2012 in addition to running the government in DIY well as it should be.

In the Privilege Law it is necessary to formulate clearly that the structure of the Government of the Special Province of Yogyakarta is unique because of its historical and cultural factors. It should be emphasized to the government that the Special Region of Yogyakarta is an area that is a special area based on legislation. Therefore the Special Region of Yogyakarta should not be equated with other regions.

\section{References}

1945 Constitution of the Republic of Indonesia.

http://www.setneg.go.id/index.php?Option=com_content\&task $=$ view\&id $=3519 \&$ Itemid $=281$.

https://eprints.uns.ac.id/363/1/151151908201009321.pdf.

Law Number 3 Year 1950 concerning Formation of Privileged Areas.

Law Number 22 Year 1999 concerning Regional Government.

Law Number 12 of 2008 concerning Regional Government.

Law Number 32 of 2004 concerning Regional Government.

Philipus M. Hadjon, Perlindungan Hukum bagi Rakyat di Indonesia, Sebuah Studi tentang Prinsip-prinsipnya, Penanganannya oleh Pengadilan dalam Lingkungan Peradilan Umum dan Pembentukan Peradilan Administrasi Negara, Bina Ilmu, Surabaya. 1987. 